\title{
Hydrochemical variability at the Upper Paraguay Basin and Pantanal wetland
}

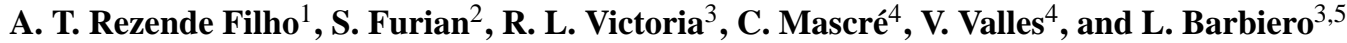 \\ ${ }^{1}$ Universidade Federal do Mato-Grosso do Sul, Departamento de Geografia, Campus de Nova Andradina, Rod. MS 134, \\ Km 3, Campus Universitário s/n, C.P. 128 79750-000, Nova Andradina-MS, Brazil \\ ${ }^{2}$ Universidade de São Paulo, Laboratório de Pedologia, Departamento de Geografia, C.P. 8105, \\ Cep 05508-900 São Paulo, Brazil \\ ${ }^{3}$ Universidade de São Paulo, Centro de Energia Nuclear na Agricultura, Laboratório de Análise Ambiental e \\ Geoprocessamento, Av. Centenário, 303, C.P. 96, Cep 13416-000 Piracicaba-SP, Brazil \\ ${ }^{4}$ Université d'Avignon et des Pays du Vaucluse, Laboratoire d'Hydrogéologie, 74 rue Louis Pasteur, \\ 84029 Avignon Cedex 01, France \\ ${ }^{5}$ Université Paul Sabatier, Géosciences Environnement Toulouse, Institut de Recherche pour le Développement, \\ Observatoire Midi-Pyrénées, 14 Av. E. Belin, 31400 Toulouse, France
}

Correspondence to: L. Barbiero (laurent.barbiero@get.obs-mip.fr)

Received: 1 March 2012 - Published in Hydrol. Earth Syst. Sci. Discuss.: 12 March 2012

Revised: 14 July 2012 - Accepted: 23 July 2012 - Published: 14 August 2012

\begin{abstract}
Compartmentalization is a prerequisite to understand large wetlands that receive water from several sources. However, it faces the heterogeneity in space and time, resulting from physical, chemical and biological processes that are specific to wetlands. The Pantanal is a vast seasonally flooded continental wetland located in the centre of South America. The chemical composition of the waters that supply the Pantanal (70 rivers) has been studied in order to establish a compartmentalization of the wetland based on soil-water interactions. A PCA-based EMMA (EndMembers Mixing Analysis) procedure shows that the chemistry of the rivers can be viewed as a mixture of 3 endmembers, influenced by lithology and land use, and delimiting large regions. Although the chemical composition of the end-members changed between dry and wet seasons, their spatial distribution was maintained. The results were extended to the floodplain by simple tributary mixing calculation according to the hydrographical network and to the areas of influence for each river when in overflow conditions. The resulting map highlights areas of high geochemical contrast on either side of the river Cuiaba in the north, and of the rivers Aquidauana and Abobral in the south. The PCAbased treatment on a sampling conducted in the Nhecolândia, a large sub region of the Pantanal, allowed the identification
\end{abstract}

and ordering of the processes that control the geochemical variability of the surface waters. Despite an enormous variability in electrical conductivity and $\mathrm{pH}$, all data collected were in agreement with an evaporation process of the Taquari River water, which supplies the region. Evaporation and associated saline precipitations (Mg-calcite, Mg-silicates $\mathrm{K}$ silicates) explained more than $77 \%$ of the total variability in the chemistry of the regional surface water sampling.

\section{Introduction}

Wetlands provide essential environmental functions, such as purifying water, nutrient cycling, reducing flooding, recharging ground water supplies, protecting shorelines and supporting a large biodiversity (Brinson et al., 1981; Turner, 1991; Whiting and Chanton, 2001; Mitsch and Gosselink, 2007). Hydrology, hydrochemistry and biogeochemistry are key drivers of wetland environments, and have been relatively well documented in temperate, tropical, sub-humid and semi-arid environments (Batzer and Sharitz, 2006; Mitsch and Gosselink, 2007; Jolly et al., 2008; Humphries et al., 2011; Tooth et al., 2012). Among the wetlands, tropical wetlands are known to be highly reactive, as permanent high 
temperatures increase the velocity of the biogeochemical reactions (Fustec and Lefeuvre, 2000; Reddy and DeLaune, 2008). Together, the reactivity and the size fully justify studying how large tropical wetlands work.

The Pantanal basin, located at the Paraguay headwaters in the centre of the South American continent, consists in a mosaic of sub-wetlands that usually differs in various aspects, i.e. hydrological, geomorphological, pedologi$\mathrm{cal}$ and geochemical. Paradoxically, although it is considered as the world's largest continental wetland $\left(0.2 \times 10^{6} \mathrm{~km}^{2}\right.$; Por, 1995), little is known about the Pantanal, which is fed by several sources of water and exerts a marked modulating effect on the Paraguay (Junk and Nunes de Cunha, 2005). Understanding the Pantanal as a whole requires the identification and distinction of compartments based on its present day functioning that could be approached through an inventory of soil-water interactions.

The Pantanal wetland shows curious or even contradictory features, in that although it is a large wetland under seasonal humid climate and flooded each year by numbers of rivers, the process of water concentration through evaporation was identified as a major process responsible for the geochemical variability over large areas (Barbiero et al., 2002). Therefore, methods commonly used in arid or semi-arid areas appear to be adapted to understand and describe the functioning of the Pantanal and to discriminate the processes involved (Barbiero et al., 2001). In this context, the chemical composition of rivers that supply the floodplain could control the geochemical path of water evaporation from the Pantanal, that leads to contrasting sub-regions according to the area of influence of each river (Hardie and Eugster, 1970; Valles et al., 1991). Basic data on the hydrochemistry of the Upper Paraguay basin are deficient. The objective of this work is to identify the chemical variations of waters supplying the Pantanal, linking the water chemistry with characteristics of drained watersheds, and to explore the relationships between these variations and soils and waters downstream, in different sub regions on the floodplain.

\section{Material and methods}

\subsection{The Pantanal wetlands}

The Pantanal wetland is a huge alluvial plain located between $15^{\circ}$ and $22^{\circ} \mathrm{S}$ and $55^{\circ}$ and $60^{\circ} \mathrm{W}$ (Fig. 1). The depression of the Pantanal is supplied and drained by the Paraguay River and its tributaries, most of them joining on the left bank, from the Brazilian surrounding mountains and plateaus. The northern, eastern and southern borders are clearly marked by the Brazilian highlands located at an altitude of about 400 to 700 m a.s.l. (Chapada dos Parecis, Serra das Araras, Chapada dos Guimarães, Serra São Jeronimo, Serra do Maracajú, Serra do Bodoquena). There is an opening in the north of the floodplain, through which the Paraguay River flows southward. In the south, the Paraguay River crosses a narrow area between the mountains in a region called "Fecho dos Morros", which is considered the limit of the upper Paraguay basin. The basin is composed of Quaternary sediments from the surrounding highlands, themselves composed of Precambrian crystalline rocks and Mesozoic sedimentary rocks.

Hot rainy summers from November to March and dry winters from April to October characterize the climate of the type "Aw" according to Köppen. The average summer temperature is roughly $32{ }^{\circ} \mathrm{C}$, while winters are dry and colder, with the possibility of occasional frost during the influx of southern polar air masses (IBGE, 2003). Overall, the Pantanal has an annual water deficit of about $300 \mathrm{~mm}$, resulting from an average annual rainfall of $1100 \mathrm{~mm}$ and an annual potential evapo-transpiration of $1400 \mathrm{~mm}$ (Alvarenga et al., 1984; Por, 1995).

The vast plain of the Pantanal provides an enormous natural control mechanism of flood waters from heavy rains during the wet period. Characterized by low slope gradients $\left(0.3\right.$ to $\left.0.5 \mathrm{~m} \mathrm{~km}^{-1}\right)$ and altitudes between 100 and $200 \mathrm{~m}$ (Assine, 2005), the plain is partially covered by seasonal flooding occurring in summer (November to March). At the local level, water and solute flows are complex (Hamilton et al., 1998) and depend on many classical factors affecting water flows in wetlands, such as the configuration of levees, slight variations in the topography, resistance to flow related to vegetation, local rainfall intensity and tributary inputs (Girard et al., 2010). In addition, in some parts of the Pantanal characterized by an absence of apparent drainage networks, the sub-surface flows are controlled by systems of thresholds between lakes (Barbiero et al., 2007, 2008). According to Hamilton et al. (1997) and on annual basis, the inflow of water in the Pantanal is nearly equivalent to the amount drained. Thus, the water lost by evaporation is roughly balanced by direct precipitation on the floodplain.

\subsection{Sampling}

A total of 70 sampling points were defined to characterize the chemistry of water entering the Pantanal. Most of these points are located where the brazilian highways surrounding the depression cross the rivers (Fig. 1). Geographic coordinates and field measurements $(\mathrm{pH}$, electrical conductivity and Temperature) are given in Table 1. Samples were commonly taken from the bridge at the centre of the stream, using a polyethylene sampler. Two sets of samples were taken, one during the dry season (DS) in July 2008 (including 37 samples), the other during the wet season (WS) in March 2010 (including 70 samples). To link the chemical variability within a sub-region with the type of water that supplies it, a third sampling was obtained across the plain in the heart of Nhecolândia ( $\mathrm{NH}$, including 74 samples), a sub-region which corresponds to the southern part of the Taquari alluvial fan (Fig. 2). The NH sampling includes waters from ponds and draining fields and was done during the 
Table 1. Field measurements and coordinates of DS and WS samplings.

\begin{tabular}{|c|c|c|c|c|c|c|c|}
\hline $\begin{array}{l}\text { Sample } \\
\text { point }\end{array}$ & River name & $\begin{array}{c}\text { X coord } \\
\text { UTM } \\
(\mathrm{m})\end{array}$ & $\begin{array}{l}\text { Y coord } \\
\text { UTM } \\
(\mathrm{m})\end{array}$ & $\begin{array}{l}\text { DS } 2008 \\
\text { EC } \\
\left(\mu \mathrm{sm}^{-1}\right)\end{array}$ & $\begin{array}{l}\text { WS } 2010 \\
\text { EC } \\
\left(\mu \mathrm{cm}^{-1}\right)\end{array}$ & $\begin{array}{l}\text { DS } 2008 \\
\text { pH }\end{array}$ & $\begin{array}{l}\text { WS } 2010 \\
\text { pH }\end{array}$ \\
\hline 1 & Cuibá & 591992 & 8278978 & 84 & 175 & 7.68 & 7.19 \\
\hline 2 & Bento Gomes & 555756 & 8231155 & 188 & 110 & 7.62 & 7.36 \\
\hline 3 & Maneta I & 561608 & 8184171 & - & 32.2 & - & 6.19 \\
\hline 4 & Boca do Vale & 565022 & 8175578 & - & 72.4 & - & 6.55 \\
\hline 5 & Cuibá & 566337 & 8173770 & 74 & 70.9 & 7.47 & 6.54 \\
\hline 6 & Bento Gomes & 548710 & 8196169 & - & 74.9 & - & 6.62 \\
\hline 7 & Das Trairas & 538175 & 8222180 & 108 & 103 & 7.43 & 7.16 \\
\hline 8 & Formiga & 517540 & 8230031 & 335 & 218 & 7.6 & 7.55 \\
\hline 9 & Figueira & 508275 & 8233985 & 297.4 & 212 & 7.47 & 7.33 \\
\hline 10 & unnamed & 508141 & 8234616 & - & 150 & - & 7.46 \\
\hline 11 & Dos Macacos & 502847 & 8238699 & - & 75.4 & - & 7.05 \\
\hline 12 & Córrego Sangradouro & 488769 & 8237437 & 354 & 62 & 8.18 & 6.8 \\
\hline 13 & Córrego Sangradorzinho & 486839 & 8238410 & 505 & 67 & 8.01 & 6.92 \\
\hline 14 & Das Flexas & 471355 & 8225208 & 262 & 100 & 8.13 & 7.35 \\
\hline 15 & Paraguai & 424761 & 8222717 & 44 & 49 & 6.95 & 6.4 \\
\hline 16 & Padre Inácio & 410123 & 8223775 & 320 & 188.5 & 7.33 & 7.14 \\
\hline 17 & Jaurú & 391309 & 8214515 & 59.2 & 115.6 & 7.5 & 6.83 \\
\hline 18 & Aricá & 618670 & 8264051 & - & 35.1 & - & 6.62 \\
\hline 19 & unnamed & 643214 & 8259231 & - & 50.4 & - & 7.12 \\
\hline 20 & Aricá Mirím & 643986 & 8256529 & - & 27.1 & - & 6.76 \\
\hline 21 & Córrego do Cervo & 644011 & 8252503 & 47.9 & 41.2 & 6.8 & 6.65 \\
\hline 22 & Aguas Quentes & 659092 & 8243162 & 27.8 & 31.4 & 6.64 & 6.96 \\
\hline $22^{*}$ & Aguas Quentes hot spring & 659092 & 8243162 & 65.2 & 69.1 & 6 & 5.75 \\
\hline 23 & São Lourenço & 722310 & 8230205 & 18.17 & 38 & 6.97 & 7.02 \\
\hline 24 & Areial & 725672 & 8225462 & - & 44.3 & - & 6.94 \\
\hline 25 & Tugoré & 737175 & 8207253 & - & 51.5 & - & 7.03 \\
\hline 26 & Vermelho & 768431 & 8177496 & 26.5 & 39 & 7.2 & 7.02 \\
\hline 27 & Inhumas & 744340 & 8134806 & - & 15.3 & - & 5.23 \\
\hline 28 & Ponte de Pedra & 738269 & 8116883 & - & 13.6 & - & 5.69 \\
\hline 29 & Cachoeira & 738334 & 8105777 & - & 11.8 & - & 5.33 \\
\hline 30 & Itiquira & 737941 & 8091244 & 16.18 & 24.8 & 6.7 & 6.99 \\
\hline 31 & Sozinho & 737773 & 8085673 & - & 10.2 & - & 5.75 \\
\hline 32 & Correntes & 739894 & 8061356 & 5.05 & 10.8 & 6.38 & 6.05 \\
\hline 33 & Benjamin & 737791 & 8038055 & - & 10.1 & - & 5.59 \\
\hline 34 & Piquirí & 744750 & 8017762 & 17.3 & 27.3 & 6.81 & 6.6 \\
\hline 35 & Claro & 748376 & 7986646 & - & 32 & - & 6.55 \\
\hline 36 & Claro & 745182 & 7963080 & - & 17.5 & - & 6.22 \\
\hline 37 & Taquarí & 738629 & 7950094 & 17.6 & 29.2 & 6.9 & 6.95 \\
\hline 38 & Coxim & 737903 & 7947151 & 32 & 33 & 6.8 & 6.7 \\
\hline 39 & Riacho Claro & 728939 & 7923208 & - & 8.7 & - & 5.61 \\
\hline 40 & Córrego Fundo & 730344 & 7916226 & - & 8.7 & - & 5.55 \\
\hline 41 & Verde (Highway) & 727168 & 7909208 & - & 16.4 & - & 6.09 \\
\hline 42 & Verde & 720637 & 7904625 & 3.55 & 8.3 & 5.5 & 5.48 \\
\hline 43 & Negrinho & 719870 & 7890980 & - & 43.7 & - & 6.78 \\
\hline 44 & unnamed & 718384 & 7882929 & - & 55.3 & - & 7.32 \\
\hline 45 & Córrego Mumbuca & 718067 & 7877005 & 17.1 & 21.5 & 6.5 & 6.38 \\
\hline 46 & Córrego Garimpo & 710840 & 7857975 & - & 52.4 & - & 6.81 \\
\hline 47 & Negro & 691628 & 7862831 & 33.7 & 36.2 & 6.92 & 6.66 \\
\hline 48 & Taboco & 641526 & 7780008 & 19.53 & 44.9 & 6.71 & 6.49 \\
\hline 49 & Dois Irmãos & 648429 & 7728861 & - & 114.9 & - & 7.85 \\
\hline 50 & Cachoeirão & 680237 & 7735017 & - & 121 & - & 7.61 \\
\hline 51 & Aquidauana & 653171 & 7734398 & 74.6 & 78.8 & 7.59 & 7.53 \\
\hline 52 & Taquarussú & 627188 & 7732732 & - & 75.1 & - & 7.18 \\
\hline 53 & Córrego Acogô & 620001 & 7732233 & 36.5 & 42.5 & 6.75 & 6.75 \\
\hline 54 & Córrego Laranjal & 599105 & 7741379 & - & 134 & - & 7.56 \\
\hline
\end{tabular}


Table 1. Continued.

\begin{tabular}{llccllll}
\hline $\begin{array}{l}\text { Sample } \\
\text { point }\end{array}$ & River name & $\begin{array}{c}\text { X coord } \\
\text { UTM } \\
(\mathrm{m})\end{array}$ & $\begin{array}{c}\text { Y coord } \\
\text { UTM } \\
(\mathrm{m})\end{array}$ & $\begin{array}{l}\text { DS 2008 } \\
\text { EC } \\
\left(\mu \mathrm{cm}^{-1}\right)\end{array}$ & $\begin{array}{l}\text { WS 2010 } \\
\text { EC } \\
\left(\mu \mathrm{cm}^{-1}\right)\end{array}$ & $\begin{array}{l}\text { DS 2008 } \\
\text { pH }\end{array}$ & $\begin{array}{l}\text { WS 2010 } \\
\text { pH }\end{array}$ \\
\hline 55 & Córrego Agachí & 588936 & 7749514 & 200 & 203 & 7.44 & 7.77 \\
56 & Miranda & 562568 & 7761352 & 249 & 181 & 7.97 & 7.39 \\
57 & Salobra & 544374 & 7763661 & 568 & 459 & 7.75 & 7.64 \\
58 & Córrego Bertione & 535998 & 7718894 & - & 515 & - & 7.80 \\
59 & Córrego Igrejinha & 509329 & 7670101 & - & 222 & - & 8.23 \\
60 & Córrego Catitú & 494183 & 7672968 & - & 55.5 & - & 7.39 \\
61 & Aquidabã & 472150 & 7695152 & 245 & 175.1 & 7.4 & 7.75 \\
62 & Naitaka & 439952 & 7718740 & 144.3 & 103.3 & 6.76 & 6.8 \\
63 & Nabileque & 434088 & 7716911 & - & 106 & - & 6.95 \\
64 & Branco & 455872 & 7651866 & 77.8 & 99.2 & 7.35 & 7.38 \\
65 & Tereré & 461640 & 7632796 & 131.5 & 68.2 & 8.54 & 7.72 \\
66 & Amonguijá & 465962 & 7610405 & 92.2 & 56.7 & 7.73 & 7.65 \\
67 & São Lourenço & 471392 & 7603639 & - & 69.3 & - & 7.59 \\
68 & Paraguay - Porto Murtinho & 408505 & 7600872 & - & 91.4 & - & 6.91 \\
69 & Nioaque & 621074 & 7661114 & 155 & 167 & 7.69 & 7.91 \\
\hline
\end{tabular}

dry season along a $50 \mathrm{~km}$ transect located in order to intersect the ENE-WSW regional drainage, aiming to maximize chemical variability.

The electrical conductivity (EC), $\mathrm{pH}$ and temperature $(T)$ were measured on aliquots. Samples were filtered $(0.42 \mu \mathrm{m}$ cellulose-acetate syringe filters) and collected in polyethylene bottles (Nalgene $125 \mathrm{ml}$ ) previously acid-washed, then placed at $4{ }^{\circ} \mathrm{C}$ in the dark. All samples were collected in duplicate.

\subsection{Analysis}

The analyses were performed within 10 days after collection. The major anions $\mathrm{SO}_{4}^{2-}, \mathrm{Cl}^{-}, \mathrm{NO}_{3}^{-}, \mathrm{NO}_{2}^{-}$were analysed by ion chromatography (Dionex DX500). The carbonate alkalinity was analysed by carbon analyser and HCl-titration for the most concentrated samples (Method of Gran, 1952). The major cations $\left(\mathrm{Na}^{+}, \mathrm{Ca}^{2+}, \mathrm{Mg}^{2+}, \mathrm{K}^{+}\right.$and silica) were analysed by ICP and $\mathrm{NH}_{4}^{+}$by continuous flow analysis.

\subsection{Data treatment}

Dry season (DS) and wet season (WS) samples were subjected to a discriminant analysis in order to determine the best variable discriminator between WS and DS. Major elements were used as continuous variables, and the being a DS or WS sample was used as qualitative variable for the discrimination. The analysis allows ranking discriminant functions according to their standardized coefficients.

A principal component analysis (PCA) based on the correlation matrix was carried out on major elements to identify, quantify and rank the factors of variability in water chemistry. The three sampling sets (DS, WS and $\mathrm{NH}$ ) were analysed separately. This procedure, based on standardized data centered on the mean and divided by the standard deviation, ensured that each variable had the same weight in the PCA, regardless of the unit used.

The objective of the PCA is to calculate a lower dimensional space $U$ defined by the eigenvectors from the PCA and to project the samples, losing minimum information from total variability. The dimension of the space $U$ depends on the number of vectors selected from the PCA. The vectors corresponding to more than $10 \%$ of variance explained were retained. Below this value, it is usually difficult to identify the process associated with the factorial axis.

The PCA on DS and WS was conducted in two steps, first $\left(\mathrm{PCA}_{1}\right)$ on the bulk variables $[C]$ and $\mathrm{EC}$, and second $\left(\mathrm{PCA}_{2}\right)$ on the variables $\left[C^{*}\right]=[C] / \mathrm{EC}$, where $[C]$ denotes the concentrations of $\mathrm{Ca}^{2+}, \mathrm{Mg}^{2+}, \mathrm{K}^{+}, \mathrm{Na}^{+}, \mathrm{Cl}^{-}, \mathrm{SO}_{4}^{2-}$, silica and alkalinity. The objective of the "standardization" by EC was to minimize the effect of concentration by evaporation, and to maximize the discrimination of the chemical profile of water.

On the other hand, the $\mathrm{PCA}_{3}$ on $\mathrm{NH}$-sampling was conducted directly on the variables $\mathrm{Na}, \mathrm{Ca}, \mathrm{Mg}, \mathrm{K}, \mathrm{NH}_{4}, \mathrm{NO}_{3}$, $\mathrm{NO}_{2}, \mathrm{Cl}, \mathrm{SO}_{4}, \mathrm{Alk}, \mathrm{Si}$ and $\mathrm{EC}$, in order to maintain the effect of the concentration by evaporation in the result.

\subsection{Mapping procedure}

A multivariate PCA-based EMMA (end-members mixing analysis) procedure has been used as a tool for mapping. Data from DS and WS were considered as resulting from a mixture of end-members, whose chemical composition was estimated from the first factorial plan of $\mathrm{PCA}_{2}$ (Christophersen and Hooper, 1992; Liu et al., 2004). The end-members were calculated independently for both DS and WS to study the variability of the end-members and samples between these two seasons. The contribution of each end-member in the 


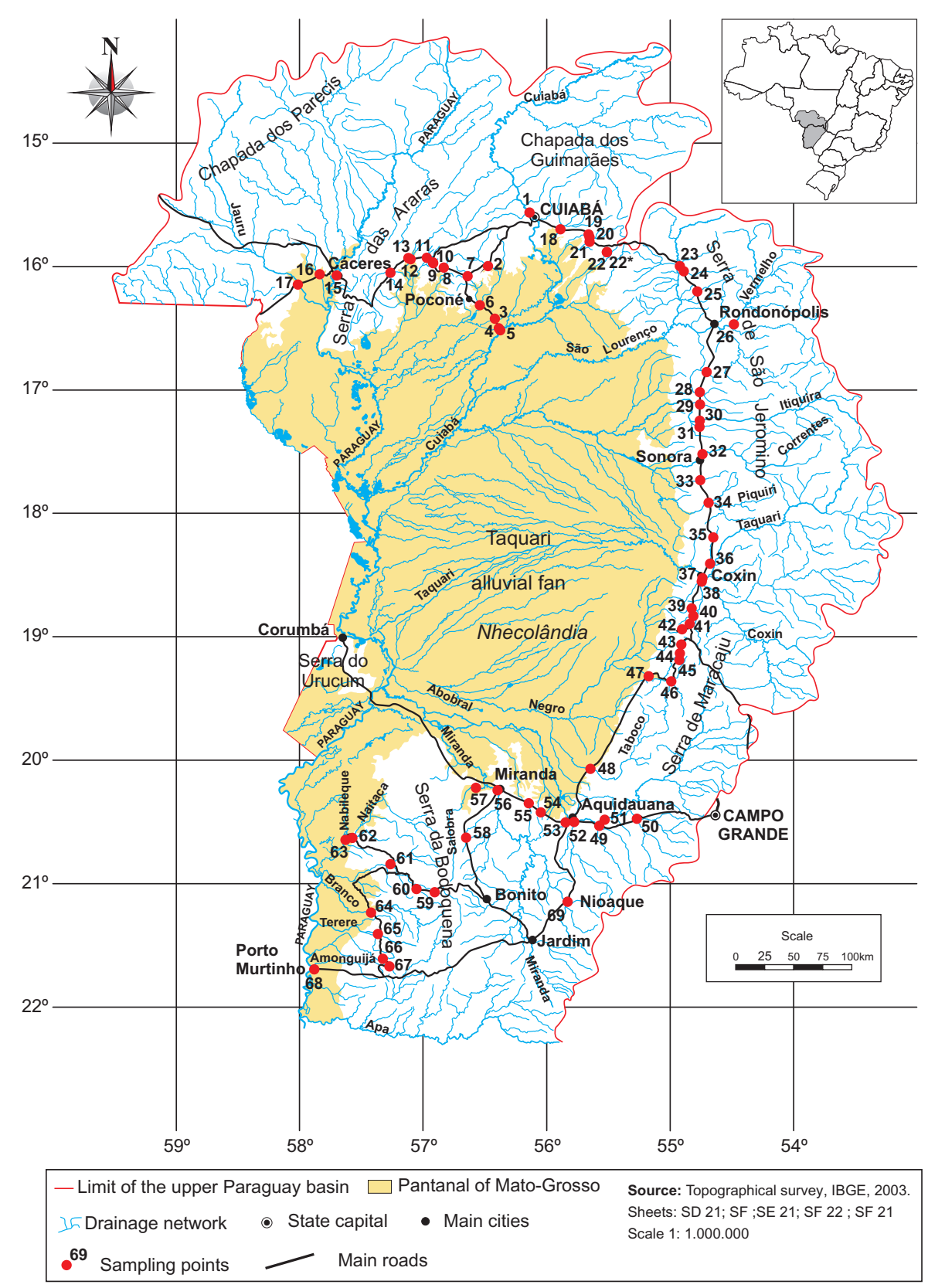

Fig. 1. The Upper Paraguay Basin, the Pantanal wetland and the Nhecolândia sub-region. Location of the sampling points DS and WS.

chemistry of a river was calculated from the distances between sample and end-members in the first factorial plan. The percentages of contribution of the end-members were used to define a mapping of the rivers chemistry.

In a second step, the chemistry was extended to the floodplain, based on the areas of influence of each river. The proportions of each end-member were recalculated when the waters are mixed at confluence downstream of the sampling points. This approach is based on the results from WS sampling and on two assumptions: (1) solutes behave conservatively during their transport and mixing of waters;
(2) water quantity increases in proportion to the drained surface area. The second point was verified in a regional report (ANA/GEF/PNUMA/OEA, 2004), where a correlation between drained area and water fluxes was founded with $r^{2}=0.93$ (Fig. 3). Under these assumptions, the proportion of end-members in the resulting mixture depends on their proportion in the contributing rivers, the electrical conductivity and the drained area according to the formula:

$$
x_{3}=\left(x_{1} \mathrm{EC}_{1} s_{1}+x_{2} \mathrm{EC}_{2} s_{2}\right) /\left(\mathrm{EC}_{1} s_{1}+\mathrm{EC}_{2} s_{2}\right)
$$




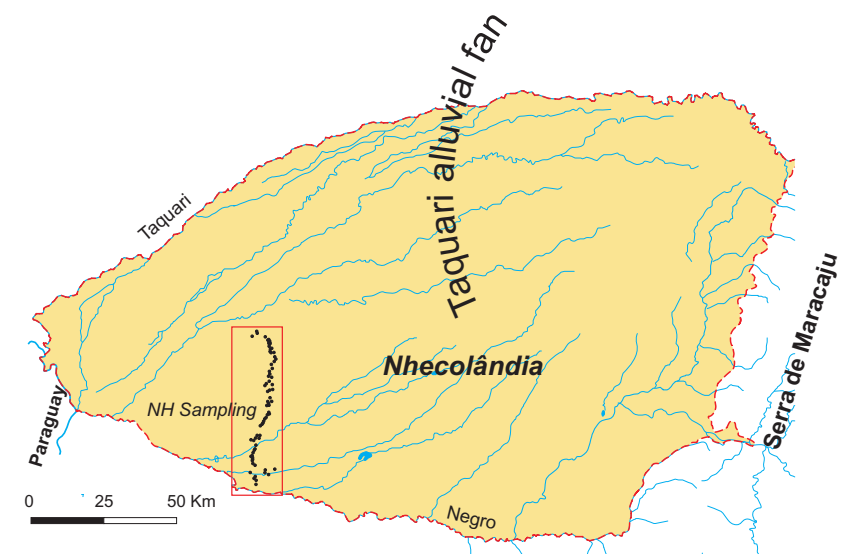

Fig. 2. Location of the sampling NH in the Nhecolândia, southern part of the Taquari alluvial fan.

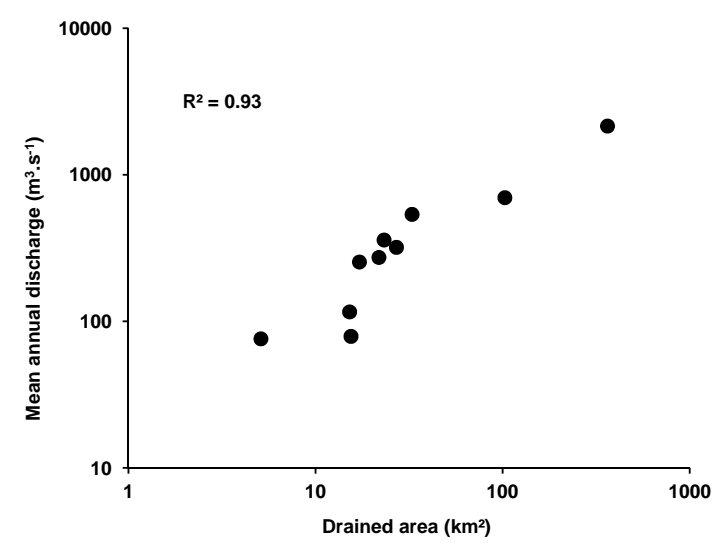

Fig. 3. Relationship between drained area and mean annual discharge in the Upper Paraguay Basin (source ANA/GEF/ PNUMA/OEA, 2004).

where $x$ is the proportion of the end-member $X$ in the chemistry of the river, EC is the electrical conductivity, $s$ is the drained area. The indices 1,2 and 3 refer to two contributing rivers and to the resulting mixture, respectively.

\subsection{Concentration diagram}

Water samples from $\mathrm{NH}$ were studied using concentration diagrams based on the sodium concentration, which was considered as an indicator of the concentration factor of the solutions. This procedure was previously described for studies conducted in the Nhecolândia (Barbiero et al., 2008).

\section{Results}

\subsection{Rivers hydrochemistry}

The descriptive statistics of DS and WS are presented in Table 2. The electrical conductivity of water varies from

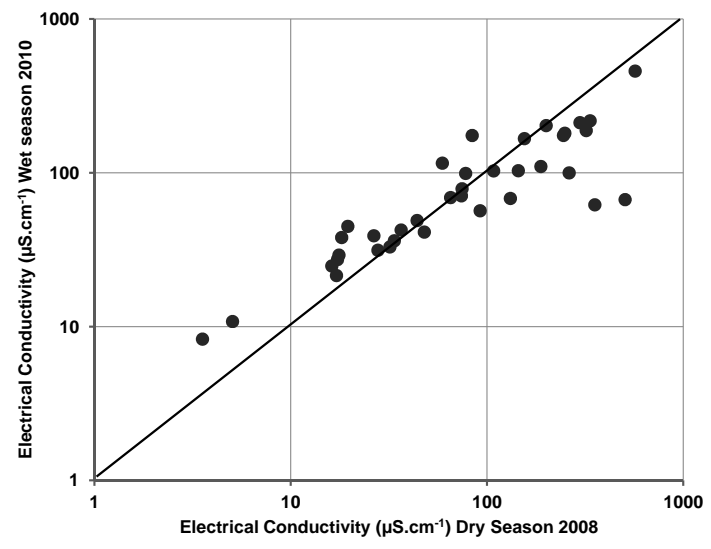

Fig. 4. Relationship between the conductivities in dry season 2008 (sampling DS) and wet season 2010 (sampling WS).

3.3 to $568 \mu \mathrm{cm}^{-1}$ during DS and 8.3 to $515 \mu \mathrm{sm}^{-1}$ during WS. Highest values were observed for rivers flowing from the Serra da Bodoquena, south of the Pantanal (Rio Salobra and Corrego Bertione, Table 1), and the lowest values were recorded from the east of the floodplain. The highest coefficients of variation were observed for $\mathrm{NO}_{3}^{-}$and $\mathrm{NH}_{4}^{+}$secondary $\mathrm{Ca}^{2+}, \mathrm{Mg}^{2+}$ and $\mathrm{Cl}^{-}$in DS, and for $\mathrm{Ca}^{2+}, \mathrm{Mg}^{2+}$, $\mathrm{SO}_{4}^{2-}$ and alkalinity in WS. Figure 4 shows the relationship between the conductivities in 2008 (DS) and 2010 (WS) for the 37 rivers that were not dry during sampling in 2008. Results indicate that the more dilute rivers were more concentrated in WS than in DS, whereas the waters with higher mineral charge are logically more diluted in WS. The increase in electrical conductivity of low charge waters between DS and WS is due to the increase in sulphate concentrations that average at a factor of 5, and on a factor of 9 for samples with low or medium conductivity.

The results from the discriminant analysis are presented in Table 3 and Fig. 5. A total of $96 \%$ of the 107 WS and DS samples tested could be discriminated based on the following variable: $\mathrm{K}, \mathrm{NO}_{2}$ and alkalinity (DS), in contrast to $\mathrm{SO}_{4}$ and $\mathrm{NH}_{4}$ (WS). The discrimination is more pronounced for samples with low or medium conductivity.

The first factorial plan of the $\mathrm{PCA}_{1}$ carried out on bulk variables $[C]$ is presented on Fig. 6 . The first factorial axis accounted for 57 and $66 \%$ of the total variability in DS and WS, respectively. For both sampling, all variables were positively associated along the first factorial axis, and the electrical conductivity had the highest weight. This reflects the strong influence of the mineralization of the samples, including a climatic effect of dilution by the rain or of concentration by evaporation during the sampling period.

Eigenvalues and eigenvectors obtained from the $\mathrm{PCA}_{2}$ carried out on "EC-standardized" variables for DS and WS separately are presented in Table 4 . The first factorial plan explained 74 and $76 \%$ of the variance in DS and WS, respectively (Figs. 7 and 8). The third factorial axis, contributing 
Table 2. Descriptive statistics of major elements in sampling DS (dry season 2008) and WS (wet season 2010).

\begin{tabular}{|c|c|c|c|c|c|c|c|}
\hline & Unit & Minimum & Maximum & $\begin{array}{l}\text { Mean } \\
\text { value }\end{array}$ & $\begin{array}{l}\text { Variance } \\
v\end{array}$ & $\begin{array}{l}\text { Standard } \\
\text { deviation }\end{array}$ & $\begin{array}{l}\text { Coefficient } \\
\text { of variation }\end{array}$ \\
\hline \multicolumn{8}{|c|}{ Dry season 2008 - 37 samples } \\
\hline $\mathrm{EC}$ & $\mu \mathrm{cm}^{-1}$ & 3.55 & 568 & 134 & 20405 & 143 & 1.07 \\
\hline $\mathrm{pH}$ & - & 5.50 & 8.5 & 7.22 & 0.4 & 0.62 & 0.09 \\
\hline $\mathrm{Ca}^{2+}$ & $\mathrm{mmol}^{-1}$ & $5 \times 10^{-3}$ & 2.2 & 0.34 & 0.22 & 0.47 & 1.40 \\
\hline $\mathrm{K}^{+}$ & $\mathrm{mmol}^{-1}$ & $5 \times 10^{-3}$ & 0.2 & 0.057 & $1.7 \times 10^{-3}$ & 0.04 & 0.72 \\
\hline $\mathrm{Mg}^{2+}$ & $\mathrm{mmol}^{-1}$ & $4 \times 10^{-4}$ & 1.5 & 0.28 & 0.15 & 0.38 & 1.39 \\
\hline $\mathrm{Na}^{+}$ & $\mathrm{mmoll}^{-1}$ & 0.01 & 0.6 & 0.14 & 0.02 & 0.15 & 1.04 \\
\hline $\mathrm{Si}$ & $\mathrm{mg}^{-1}$ & 4.3 & 17.0 & 8.9 & 13.6 & 3.68 & 0.41 \\
\hline $\mathrm{Cl}^{-}$ & $\mathrm{mmoll}^{-1}$ & $5 \times 10^{-3}$ & 0.28 & 0.033 & 0.002 & 0.045 & 1.37 \\
\hline $\mathrm{NO}_{2}^{-}$ & $\mathrm{mmoll}^{-1}$ & nd & 0.048 & 0.006 & $10^{-4}$ & 0.012 & 1.87 \\
\hline $\mathrm{SO}_{4}^{2-}$ & $\mathrm{mmol}^{-1}$ & nd & 0.059 & 0.009 & $10^{-4}$ & 0.01 & 1.16 \\
\hline $\mathrm{NO}_{3}^{-}$ & $\mathrm{mmol}^{-1}$ & nd & 0.025 & 0.005 & $4 \times 10^{-5}$ & 0.006 & 1.09 \\
\hline $\mathrm{NH}_{4}^{+}$ & $\mathrm{mmoll}^{-1}$ & nd & 0.014 & 0.002 & $10^{-5}$ & 0.003 & 1.40 \\
\hline Alk. & $\mathrm{mmol}_{\mathrm{c}}$ & $9 \times 10^{-3}$ & 6.9 & 1.36 & 2.8 & 1.68 & 1.23 \\
\hline \multicolumn{8}{|c|}{ Wet season $2010-69$ samples } \\
\hline $\mathrm{EC}$ & $\mu \mathrm{scm}^{-1}$ & 8.3 & 515 & 86 & 7932 & 89 & 1.04 \\
\hline $\mathrm{pH}$ & - & 5.23 & 8.23 & 6.87 & 0.47 & 0.69 & 0.10 \\
\hline $\mathrm{Ca}^{2+}$ & $\mathrm{mmol}^{-1}$ & $4.2 \times 10^{-3}$ & 3.29 & 0.34 & 0.32 & 0.57 & 1.68 \\
\hline $\mathrm{K}^{+}$ & $\mathrm{mmoll}^{-1}$ & $5.5 \times 10^{-3}$ & 0.07 & 0.0211 & 0.0002 & 0.013 & 0.61 \\
\hline $\mathrm{Mg}^{2+}$ & $\mathrm{mmoll}^{-1}$ & $4 \times 10^{-4}$ & 2.27 & 0.2348 & 0.1151 & 0.34 & 1.45 \\
\hline $\mathrm{Na}^{+}$ & $\mathrm{mmol}^{-1}$ & $1.34 \times 10^{-2}$ & 0.28 & 0.0618 & 0.0029 & 0.054 & 0.87 \\
\hline $\mathrm{Si}$ & $\mathrm{mg} 1^{-1}$ & 2.9 & 23.3 & 6.87 & 15.12 & 3.89 & 0.57 \\
\hline $\mathrm{Cl}^{-}$ & $\mathrm{mmoll}^{-1}$ & $2 \times 10^{-3}$ & 0.18 & 0.0318 & 0.0008 & 0.029 & 0.91 \\
\hline $\mathrm{NO}_{2}^{-}$ & $\mathrm{mmol}^{-1}$ & nd & 0.014 & 0.001 & $4.53 \times 10^{-6}$ & 0.002 & 1.61 \\
\hline $\mathrm{SO}_{4}^{2-}$ & $\mathrm{mmol1}^{-1}$ & $4.2 \times 10^{-3}$ & 0.33 & 0.046 & 0.003 & 0.059 & 1.27 \\
\hline $\mathrm{NO}_{3}^{-}$ & $\mathrm{mmol}^{-1}$ & nd & 0.047 & 0.0069 & $5.2 \times 10^{-5}$ & 0.007 & 1.22 \\
\hline $\mathrm{NH}_{4}^{+}$ & $\mathrm{mmol}^{-1}$ & nd & 0.029 & 0.016 & $9.2 \times 10^{-5}$ & 0.01 & 0.61 \\
\hline Alk & $\mathrm{mmol}_{\mathrm{c}}$ & 0.009 & 5.414 & 0.573 & 0.799 & 0.89 & 1.56 \\
\hline
\end{tabular}

Higher values of the coefficient of variation are in bold.

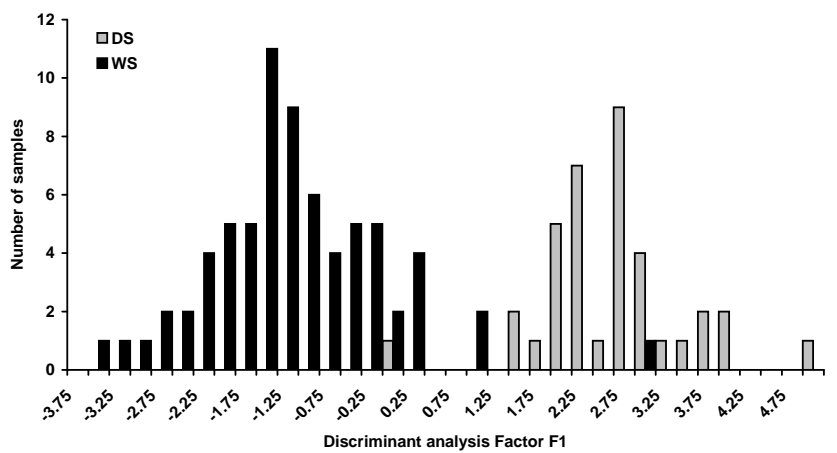

Fig. 5. Discrimination of samplings DS and WS based on major elements along factor $\mathrm{F} 1$. less than $10 \%$ of the total variance, was not considered, and it is in the plane $\mathrm{U} 1-\mathrm{U} 2$ that the samples and variables have been projected.

In this projection, the samples were distributed in a triangle, providing evidence that the river waters can be considered as a mixture from three end-members. Among these three end-members, end-member 3 characterized the most concentrated waters and was associated with the variables alkalinity, $\mathrm{Ca}$ and $\mathrm{Mg}$. It is particularly clear for samples 57, 56, 12 and 13. End-member 1 characterized diluted waters with strong influence of silica and $\mathrm{SO}_{4}$ in DS, and silica and $\mathrm{Na}$ in WS. This end-member is noticeable for two rivers in DS (42 and 32), and samples 29, 31, 33, 39, 40 in WS. Endmember 2 was associated with samples $22,22^{*}$ without being clearly associated with one variable in 2008 (DS), whereas it was clearly associated with higher amounts of $\mathrm{SO}_{4}^{2-}$ in 2010 (WS). The chemical composition of the end-member 3 was substantially the same in DS and WS, but that of the 

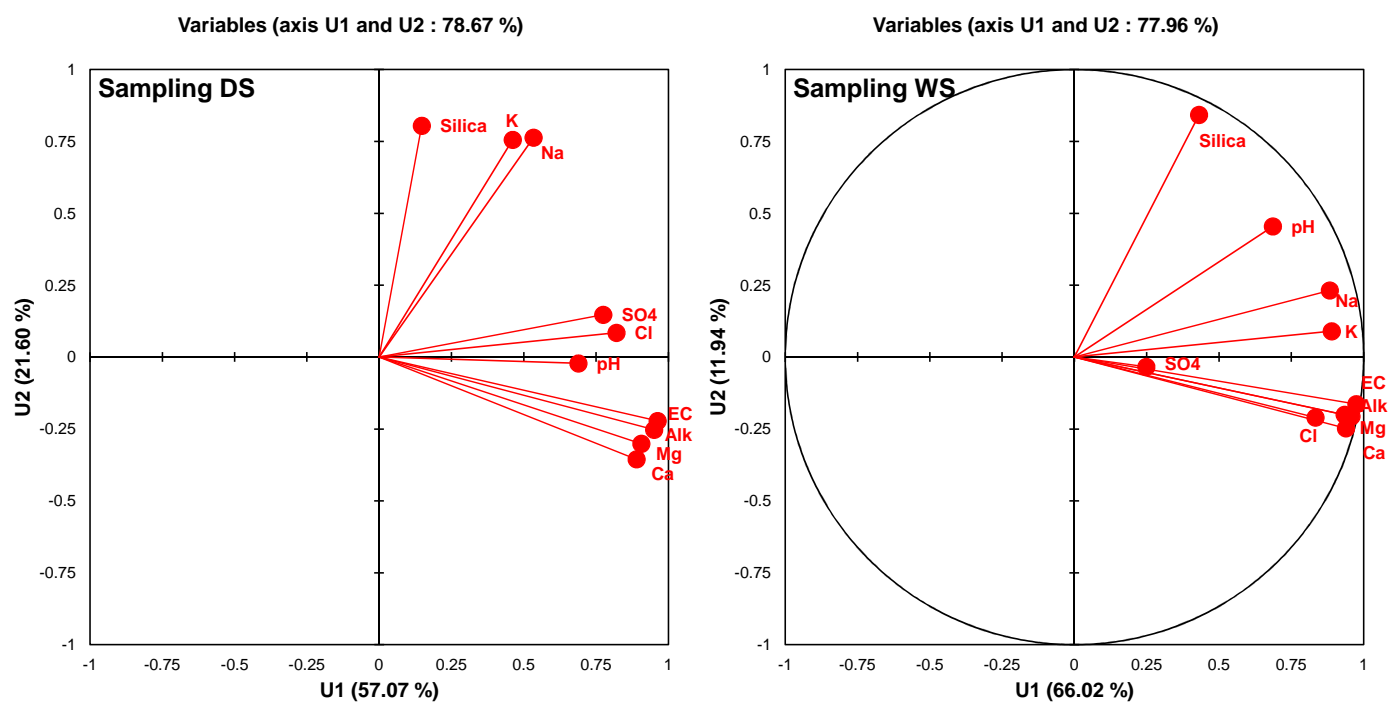

Fig. 6. Variables distribution on the first factorial plan of the $\mathrm{PCA}_{1}$ carried out on DS and WS samplings.
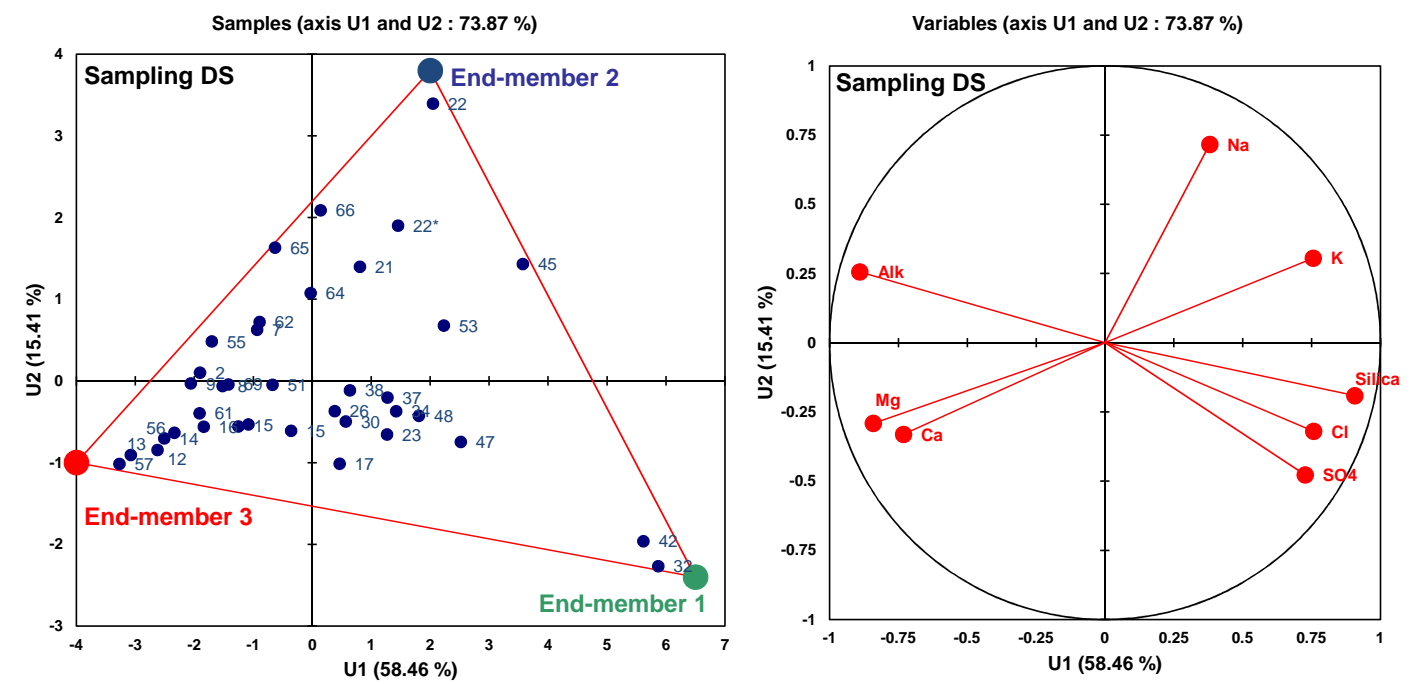

Fig. 7. Sample and variable distributions on the first factorial plan of the $\mathrm{PCA}_{2}$ carried out on DS sampling.

end-members 1 and 2 changed mainly under the influence of sulphate concentrations between DS and WS.

The results of the EMMA analysis are spatially represented on Fig. 9a (DS) and b (WS). Despite the change detected in the chemical composition of end-members 1 and 2 (Figs. 7 and 8), the spatial distribution of the end-members was largely similar in WS and DS samples. The strongest influence of end-member 1 was limited to two narrow regions on the eastern edge of the Pantanal. The influence of the end-member 3 clearly marked two large regions: one located in the north, from the Padre Inácio River in the west to the Cuiaba River in the east, and another one in the south from Aquidaban River in the west to Corrego Agachi in the east. Two features should be emphasised however: (1) the percentage of influence of this end-member 3 decreased between DS and WS in the region located to the north, (2) the area of influence of this end-member increased south of the city of Aquidauana in WS.

\subsection{Influence of the river chemistry on the Pantanal floodplain}

The water chemistry extended to the Pantanal floodplain is shown in Fig. 10. Several points are worth noting. The influence of end-member 1 disappeared at the first confluence, due to the low EC (from 3 to $10 \mu \mathrm{sm}^{-1}$ ) of waters involved. Thus, end-members 2 and 3 had a major influence on the floodplain, except at the extreme south of the Pantanal along the river Amonguija. The influence of end-member 2 dominated about $70 \%$ of the floodplain area, covering the 

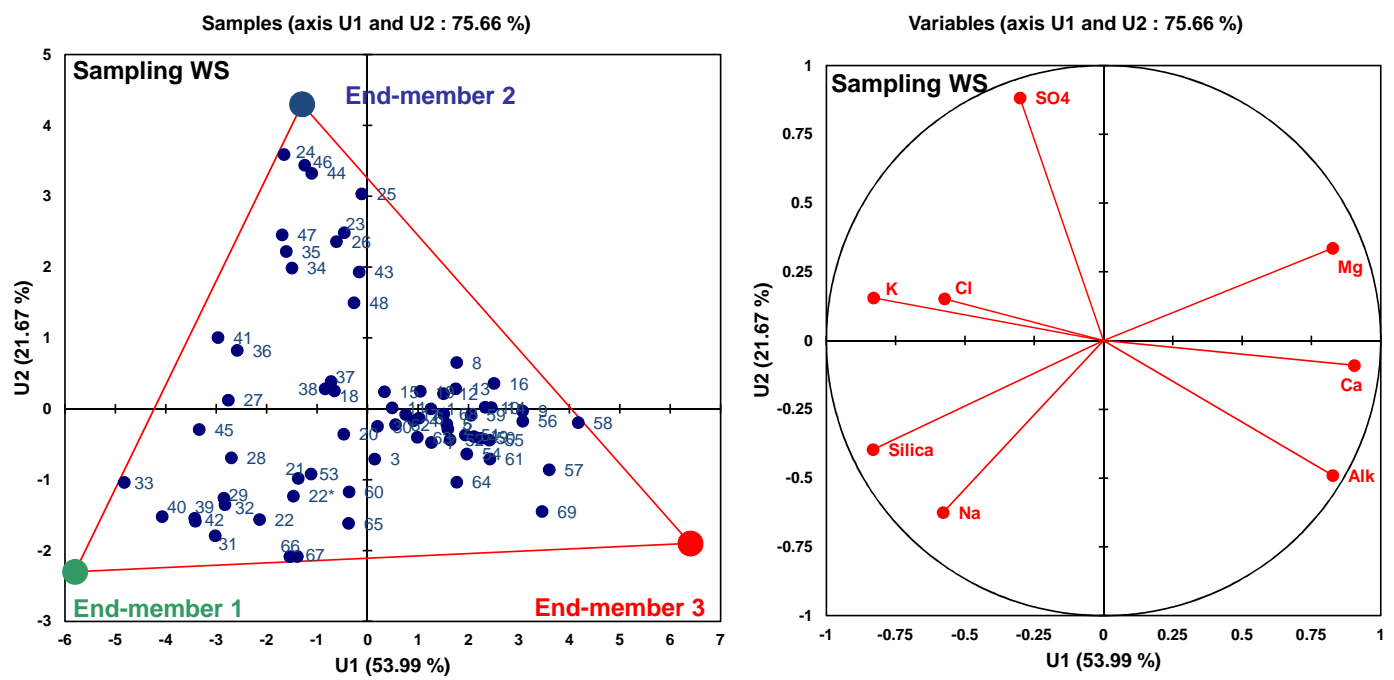

Fig. 8. Samples and variables distributions on the first factorial plan of the $\mathrm{PCA}_{2}$ carried out on WS sampling.

Spatialization of End-Members - Dry season (a)

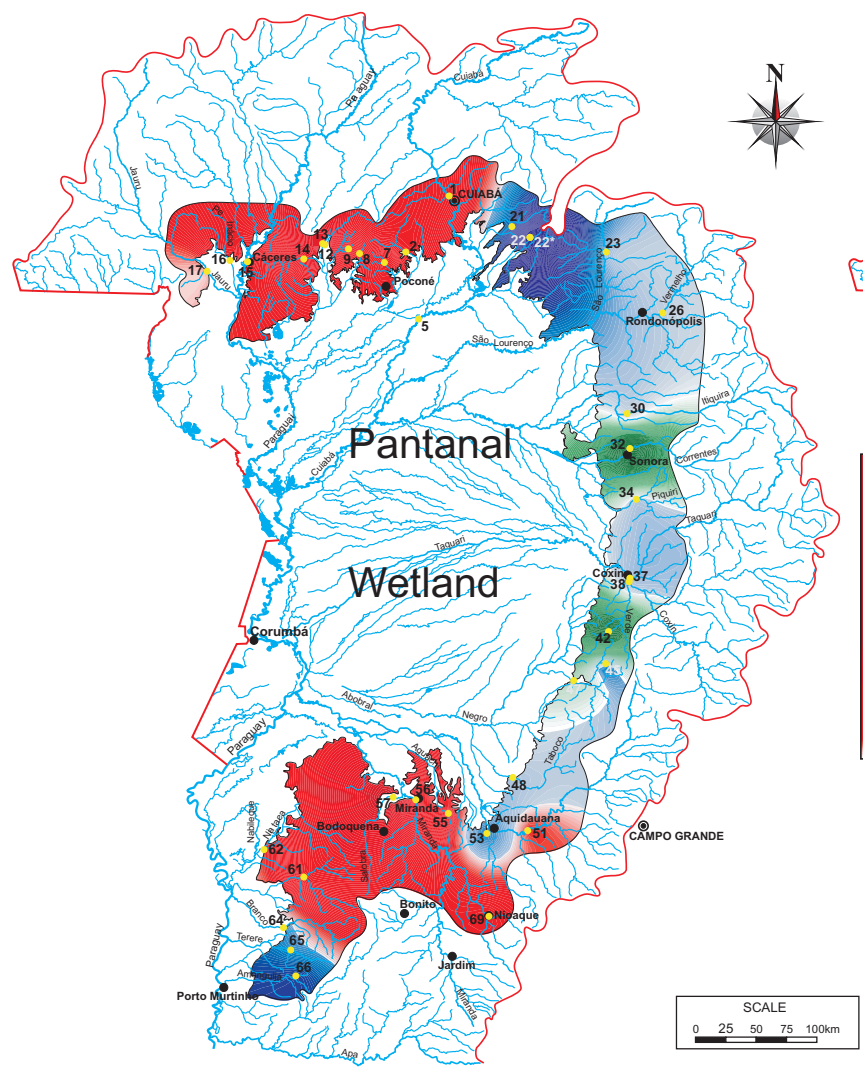

Spatialization of End-Members - Wet season (b)



Fig. 9. Chemistry of river water at the border of the Pantanal wetland during DS 2008 (a) and WS 2010 (b), deducted from PCA-based EMMA procedure (green: end-member 1, blue: end-member 2, red: end-member 3; contributions above $35 \%$ are drawn).

Taquari, São Lourenço and Taboco alluvial fans, and the Negro river basin. The shift to the compartment of the Pantanal influenced by the end-member 3 was located along the river Cuiaba in the north of the wetland, along the river
Aquidauana in the south, then along the river Abobral further west. 


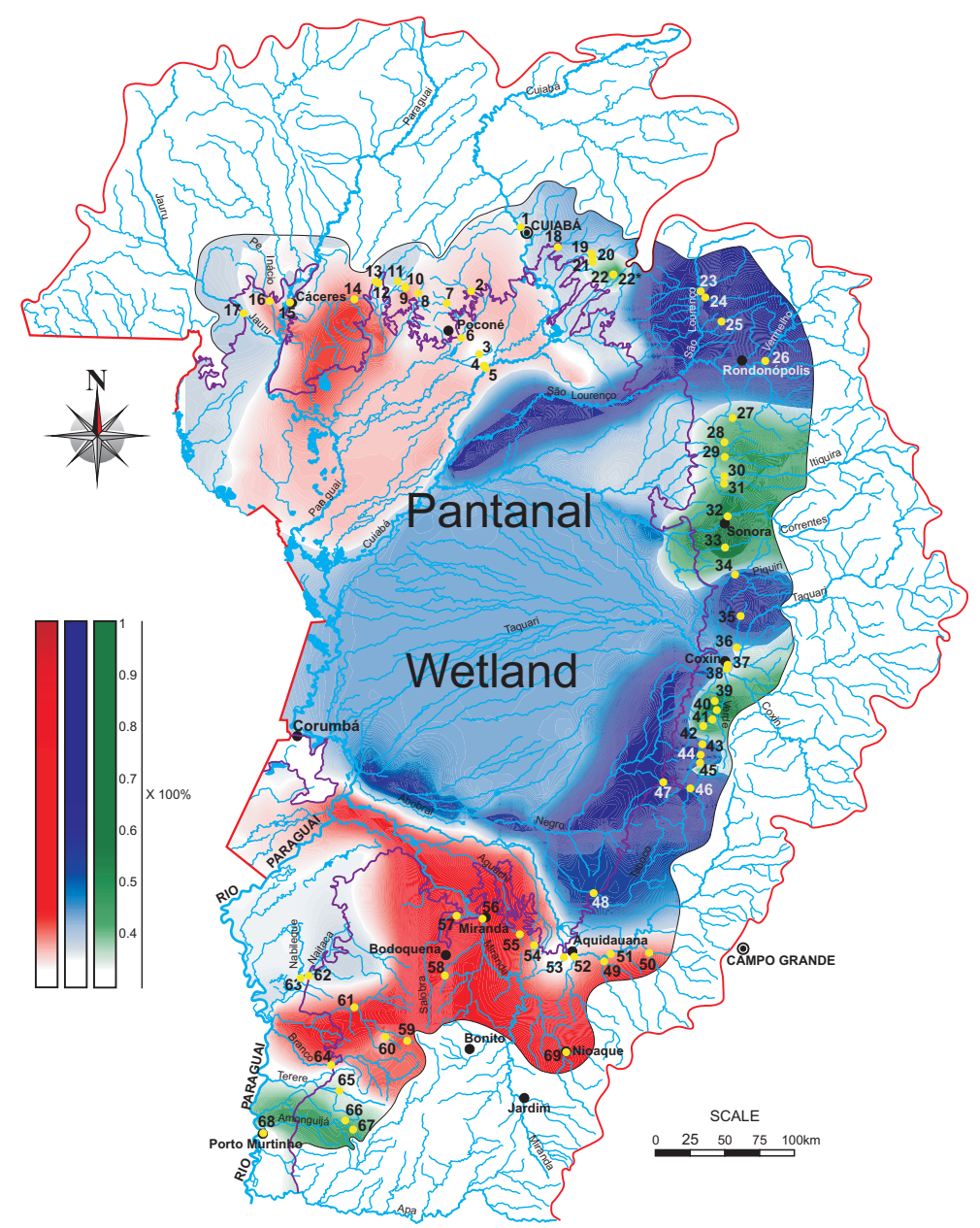

Fig. 10. Extension of the water chemistry in the Pantanal floodplain by simple tributary mixing calculation based on WS sampling (green: end-member 1, blue: end-member 2, red: end-member 3; contributions above $35 \%$ are drawn).

Table 3. Results of the discriminant analysis based on major elements and carried out on samplings DS and WS.

\begin{tabular}{lrrrr}
\hline $\begin{array}{l}\text { Observed/ } \\
\text { predicted }\end{array}$ & DS & WS & Total & $\%$ correct \\
\hline DS & 36 & 1 & 37 & $97.3 \%$ \\
WS & 3 & 67 & 70 & $95.71 \%$ \\
\hline Total & 39 & 68 & 107 & $96.26 \%$ \\
\hline
\end{tabular}

\subsection{Chemical variability in the Nhecolândia}

The descriptive statistics of the sampling $\mathrm{NH}$ are shown in Table $5 . \mathrm{Cl}^{-}$and $\mathrm{Na}^{+}$, which are generally the most "conservative" chemical elements, showed the highest coefficients of variation. The data set showed strong ranges of electrical conductivity $\left(7 \mu \mathrm{sm}^{-1}<\mathrm{CE}<5820 \mu \mathrm{sm}^{-1}\right)$ and $\mathrm{pH}$ $(5.61<\mathrm{pH}<10)$. Despite this strong contrast, the first factorial plan (Fig. 11) explained a large percentage of the
Table 4. Results of the PCA carried out on samplings DS and WS.

\begin{tabular}{lcrlcr}
\hline & \multicolumn{2}{c}{ DS - Dry Season 2008 } & & \multicolumn{2}{c}{ WS - Wet Season 2010 } \\
\cline { 2 - 3 } \cline { 5 - 6 } $\begin{array}{l}\text { Factorial } \\
\text { axis }\end{array}$ & Eigenvalue & $\begin{array}{r}\% \\
\text { of var. }\end{array}$ & & Eigenvalue & $\begin{array}{r}\% \\
\text { of var. }\end{array}$ \\
\hline 1 & & 58.46 & & 4.32 & 53.99 \\
2 & 1.23 & 15.41 & & 1.73 & 21.67 \\
3 & 0.74 & 9.29 & & 0.76 & 9.47 \\
\hline
\end{tabular}

variance $(77 \%)$. The first axis ( $61.3 \%$ of the variance) was significantly associated with variables EC, alkalinity, $\mathrm{Na}^{+}$, $\mathrm{Cl}^{-}, \mathrm{SO}_{4}^{2-}, \mathrm{K}^{+}$, and with the most concentrated samples (1, 74 and 75$)$. The second axis (15.4\% of the variance) was discriminated by the variables $\mathrm{Ca}^{2+}$ and $\mathrm{Mg}^{2+}$ and associated with samples of intermediate concentration. The third axis $(10.5 \%$, not shown) opposed two forms of nitrogen, $\mathrm{NO}_{3}^{-}$and $\mathrm{NH}_{4}^{+}$. This third axis was largely influenced by the 

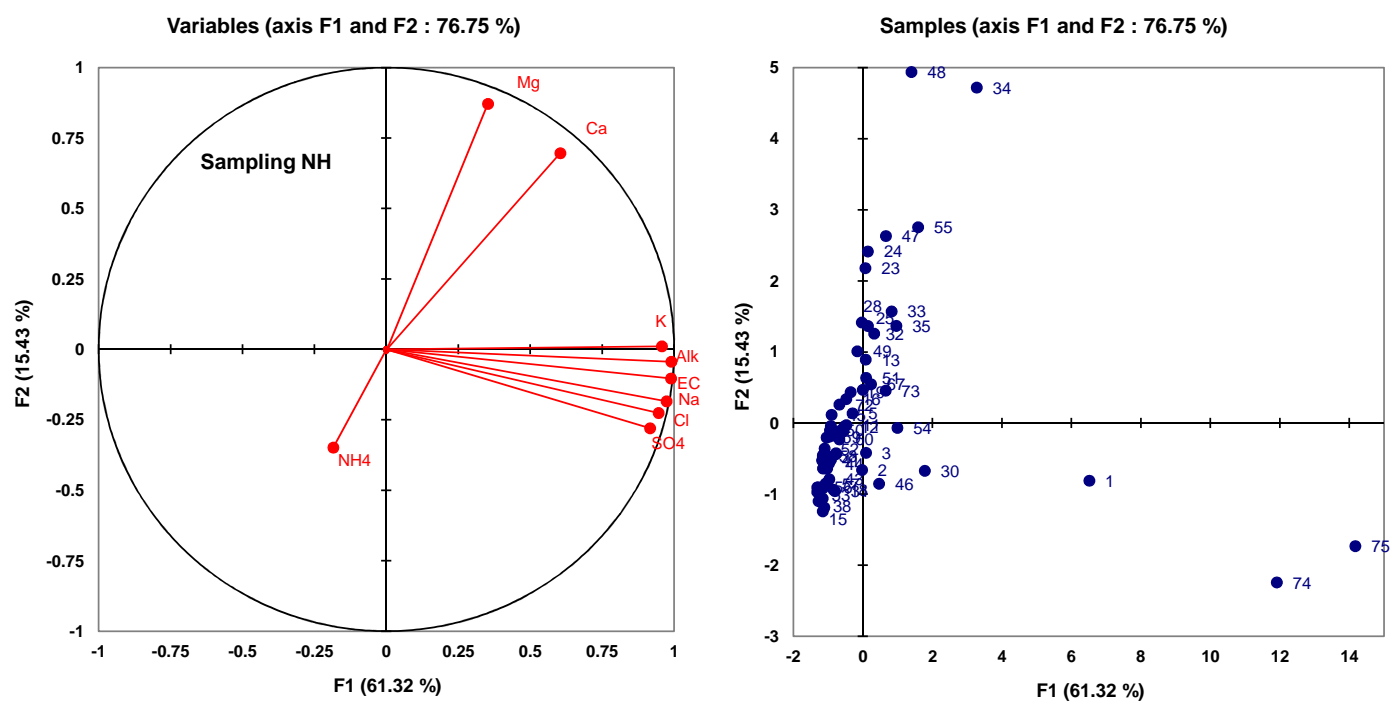

Fig. 11. First factorial plan of the $\mathrm{PCA}_{3}$ carried out on sampling NH.
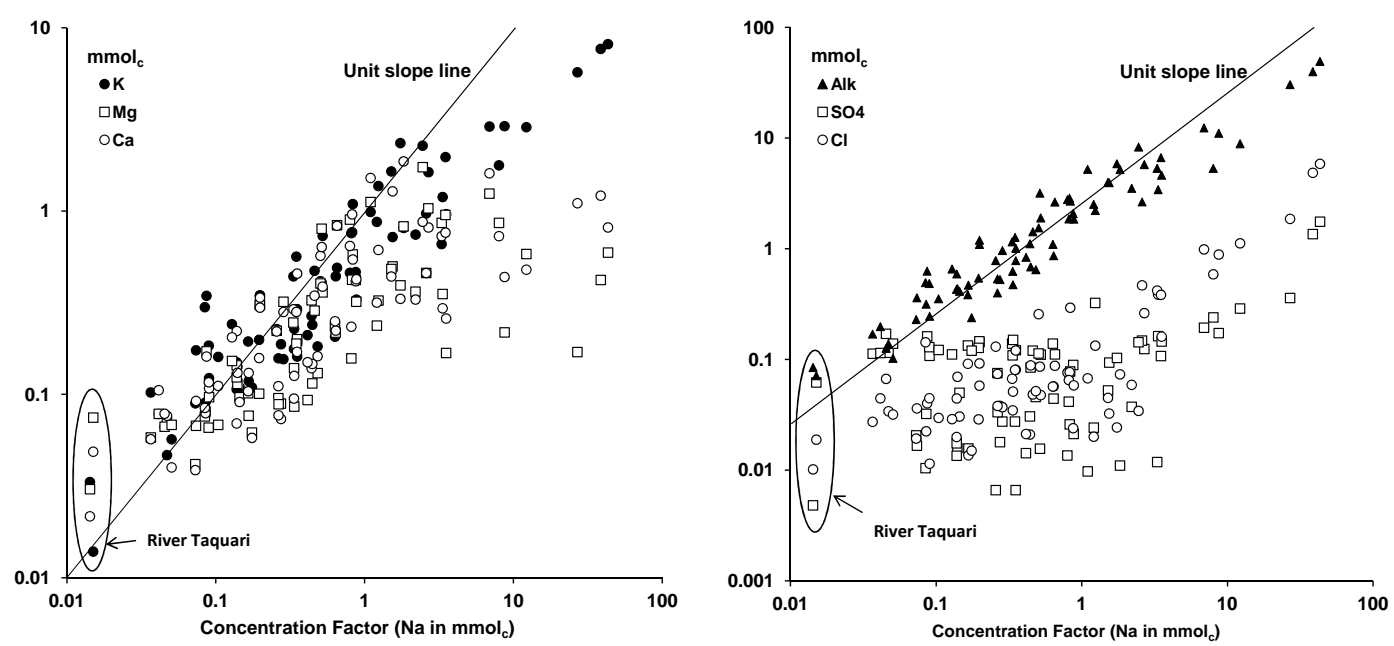

Fig. 12. Concentration diagrams for major elements of sampling NH and river Taquari (sample 37 from samplings DS and WS).

chemistry of sample 54 , showing a particularly high nitrate content.

The concentration diagram for NH waters (Fig. 12) indicates that $\mathrm{pH}$ and alkalinity increase with water mineralization. The alkalinity increases in proportion to $\mathrm{Na}^{+}$for $\mathrm{Na}^{+}$ values ranging from 5 to $20 \mathrm{mmol}_{\mathrm{c}}$, then slower for higher $\mathrm{Na}^{+}$concentration factors. Meanwhile, the plots representing $\mathrm{Ca}^{2+}$ and $\mathrm{Mg}^{2+}$ increased in proportion to $\mathrm{Na}^{+}$and then decreased significantly for the most concentrated samples. The scatter plots of $\mathrm{Cl}^{-}$and $\mathrm{SO}_{4}^{2-}$ are widely dispersed due to their relative low concentrations. The levels of $\mathrm{K}^{+}$increase throughout the concentration diagram, but more slowly than sodium. The waters of the river Taquari are the most diluted samples, and are in direct continuation with the scatter plot of the waters from the Nhecolândia.

\section{Discussion}

The chemical variability of the rivers that supply the Pantanal wetland is controlled primarily by a lithological factor (Fig. 13). The end-member 3 is spatially associated with calcareous formations located in the north (Serra das Araras) and in the south (Serra da Bodoquena). The influence of this end-member to the south of the city of Aquidauana in the rainy season should be attributed to the drainage from the basalts of the Serra Geral formation in the upper part of the Aquidauana watershed. End-members 1 and 2 are associated with sandstone formations and crystalline rocks in the eastern, north-western and the narrow southern part of the wetland. Although they were clearly discriminated on the $U$ space (Figs. 7 and 8), the distinction between end-members 1 
Table 5. Descriptive statistics of major elements in sampling NH (Nhecolândia).

\begin{tabular}{lllrllcc}
\hline & Unit & Minimum & Maximum & $\begin{array}{l}\text { Mean } \\
\text { value }\end{array}$ & $\begin{array}{l}\text { Variance } \\
v\end{array}$ & $\begin{array}{c}\text { Standard } \\
\text { deviation }\end{array}$ & $\begin{array}{c}\text { Coefficient } \\
\text { of variation }\end{array}$ \\
\hline $\mathrm{EC} \mathrm{ms} \mathrm{cm}^{-1}$ & 0.007 & 5.82 & 0.41 & 0.996 & 0.998 & 2.43 & \\
$\mathrm{Cl}^{-}$ & $\mathrm{mmoll}^{-1}$ & 0.011 & 5.87 & 0.29 & 0.826 & 0.909 & 3.16 \\
$\mathrm{SO}_{4}^{2-}$ & $\mathrm{mmoll}^{-1}$ & 0.003 & 0.88 & 0.064 & 0.016 & 0.125 & 1.93 \\
$\mathrm{NO}_{3}^{-}$ & $\mathrm{mmoll}^{-1}$ & nd & 0.72 & 0.033 & 0.008 & 0.092 & 2.82 \\
$\mathrm{NH}_{4}^{+}$ & $\mathrm{mmoll}^{-1}$ & nd & 0.07 & 0.009 & 0.0002 & 0.017 & 1.91 \\
$\mathrm{Ca}^{2+}$ & $\mathrm{mmoll}^{-1}$ & 0.013 & 1.26 & 0.22 & 0.060 & 0.246 & 1.11 \\
$\mathrm{Mg}^{2+}$ & $\mathrm{mmoll}^{-1}$ & 0.012 & 1.36 & 0.19 & 0.052 & 0.228 & 1.23 \\
$\mathrm{Na}^{+}$ & $\mathrm{mmoll}^{-1}$ & 0.027 & 43.10 & 2.41 & 52.22 & 7.228 & 2.99 \\
$\mathrm{~K}^{+}$ & $\mathrm{mmoll}^{-1}$ & 0.034 & 8.14 & 0.87 & 2.26 & 1.504 & 1.74 \\
$\mathrm{Alk}$ & $\mathrm{mmol}_{\mathrm{c}}$ & 0.102 & 49.44 & 3.68 & 64.02 & 8.002 & 2.18 \\
\hline
\end{tabular}

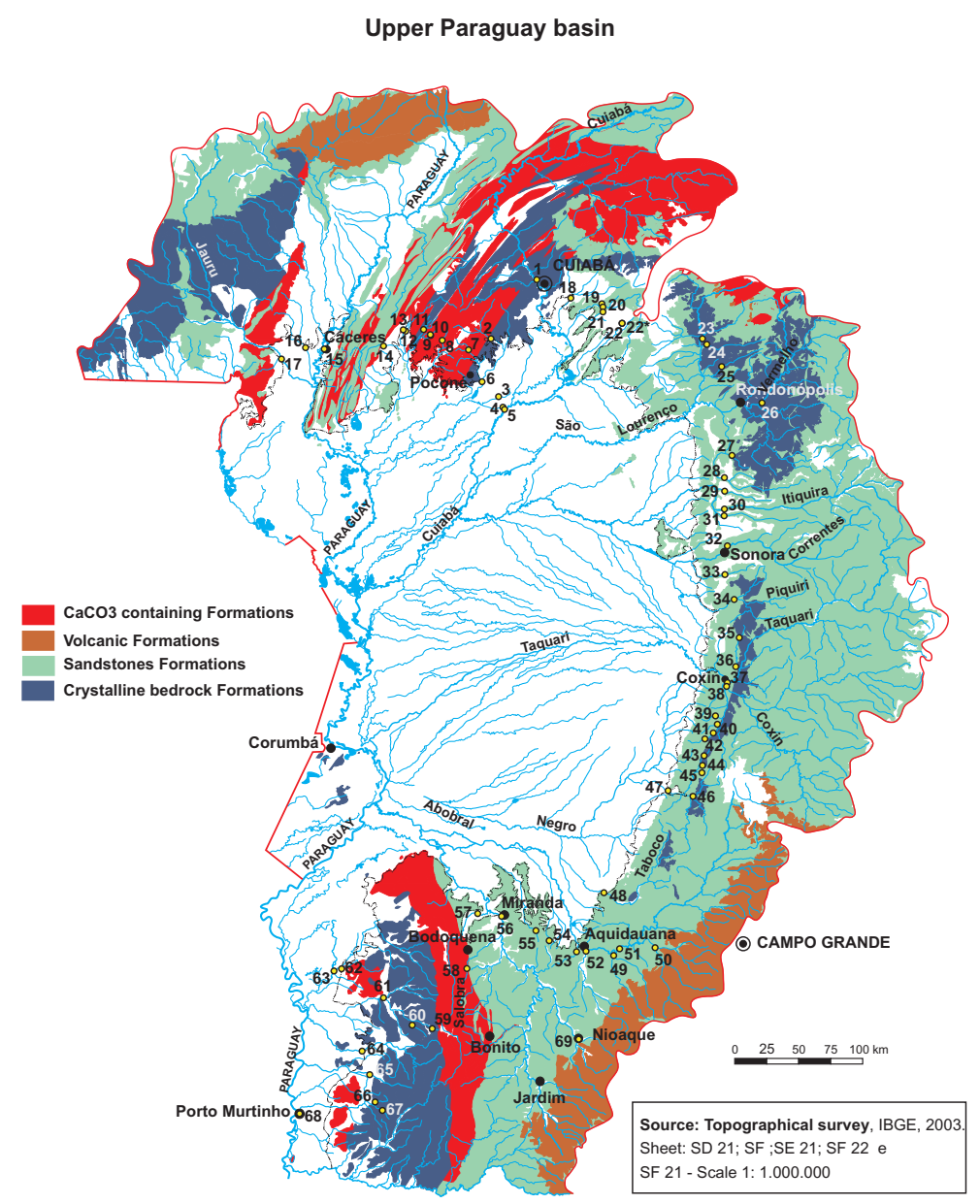

Fig. 13. Simplified map of the lithology of the Upper Paraguay Basin.

and 2 is more difficult to interpret, especially due to low mineral charge.

Increasing concentrations of $\mathrm{SO}_{4}^{2-}$ during the wet season is most likely the result of a different path of the water. In DS, the rivers are exclusively fed by the base flow from the sandstone formations, with very low $\mathrm{SO}_{4}^{2-}$ charge. During the wet season, the rivers are fed by a larger amount of surface runoff from the extensive agricultural systems of soybeans, sorghum and cotton on the surrounding plateau. There, sulphate is regularly applied through the nitrogen 
fertilization, mainly in the form of ammonium sulphate. With these regular human practices, sulphate is known to leach into inland aquatic ecosystems and it is increasingly being seen as an issue in wetland management (Lamers et al., 1998, 2001; Baldwin and Mitchell, 2012). The association of ammonium and sulphate is consistent with the discrimination observed between DS and WS (Table 3). Moreover, the assimilation of nitrogen as $\mathrm{NH}_{4}^{+}$is a factor of acidification of the soil solution (Valles et al., 1993), which may explain why $\mathrm{SO}_{4}$ and $\mathrm{NH}_{4}$ variables are in contrast to the alkalinity on the discriminant analysis.

The variability in water chemistry within the Nhecolândia sub-region is mainly due to the influence of evaporation. The evolution of the samples on the concentration diagrams (Fig. 12) is similar to that observed in local studies in the same region. The region is fed by the Taquari River, which has diluted water, with positive calcite residual alkalinity. In these conditions, and under the influence of the evaporation, calcite may precipitate, with an increase in alkalinity and a decrease in calcium content (Barbiero et al., 2008). In these alkaline conditions, the magnesium appears to be also controlled and maintained at low concentration by two processes: (i) the incorporation in $\mathrm{Mg}$-calcite in proportion of about 5 to $7 \%$ and, (ii) the formation of $\mathrm{Mg}$-silicates of stevenstite and saponite types around saline lakes (Furquim et al., 2008, 2010a). Furquim et al. (2010b) suggested that the control of potassium could be attributed to the formation of Fe-illite, although the thermodynamic pathways favouring illite neoformation in alkaline-saline environments have not been identified.

The plot of $\mathrm{Cl}^{-}$and $\mathrm{SO}_{4}^{2-}$, and in particular the scattered distribution for low charge waters, cannot be attributed to a concentration/dilution process. Instead we suggest several hypotheses to explain the appearance of the scatter plots on the concentration diagram. For instance, there may be a local effect of adsorption on minerals with a R-OH structure, as it is the case of $\mathrm{Mg}$-silicates according to the reaction:

$\mathrm{R}(\mathrm{Si}, \mathrm{Mg}, \ldots)-\mathrm{OH}+\mathrm{Cl}^{-} \rightarrow \mathrm{R}(\mathrm{Si}, \mathrm{Mg}, \ldots)-\mathrm{Cl}+\mathrm{OH}^{-}$

In the most concentrated waters, the high alkalinity prevents this reaction and $\mathrm{Cl}^{-}$evolves conservatively in relation to sodium. Sulphate concentrations are low and the scatter distribution in Fig. 12 could be attributed to the local impact of redox processes related to the flood intensity. Barbiero et al. (2008) showed that local pedological processes have a strong influence in dissolved $\mathrm{Cl}^{-}$and $\mathrm{SO}_{4}^{2-}$. We should also keep in mind that the fertilization in the surrounding highland is based on $\left(\mathrm{NH}_{4}\right)_{2} \mathrm{SO}_{4}$ and $\mathrm{KCl}$. Therefore, higher concentration of $\mathrm{Cl}^{-}$and $\mathrm{SO}_{4}^{2-}$ in the floodplain could be also attributed to an effect of the upstream fertilization. It is not possible to decide between these different hypotheses solely on the basis of the major elements. An isotopic study could provide complementary information.

\section{Conclusions}

The chemistry of the waters that supplies the Pantanal consisted of a mixture of three end-members that depend mainly on the local lithology and land use (approximately 60 and $15 \%$ of the total variability, respectively). The influence of land use, attributed to the presence of large crops on the edge of the Pantanal, increased during the wet season. This is probably due to a greater contribution of surface runoff that results in a considerable increase of the proportion of $\mathrm{SO}_{4}^{2-}$ and a decrease in the alkalinity. Other sources of variability appeared entrenched in the geochemical background level. Despite the differences in end-member composition between wet and dry seasons (WS and DS), the spatial distribution of water chemistry highlighted the same compartments on the periphery of the Pantanal wetland.

The extension of the water chemistry by simple tributary mixing calculations showed that mainly two families of waters dominate the alluvial plain. It further revealed two areas of strong chemical contrast; one along the Cuiabá River, and the other along the Aquidauana and Abobral Rivers.

This work centres on understanding the hydrochemistry of the Upper Paraguay Basin. Future work should focus on water chemistry at the outlet of the Pantanal and along the Paraguay River, which is the main collector of the wetland.

Within the Nhecolândia, the gradual and continuous chemical changes from the most diluted to the most concentrated waters allowed us to link their origin to the Taquari River water. The chemical variability can be attributed to the influence of evaporation (over $77 \%$ of the total chemical variability) in a well-known geochemical context and already described. We confirm here that the results obtained from previous local scale studies are representative. However, one may question the strong influence of evaporation across the region, because the current climatic conditions would be barely propitious for maintaining the high evaporation of water that could lead to the observed salinities. Therefore, multi-scale future investigations should aim to better understand the distribution of the chemical variability in the landscape of Nhecolândia, and identify the processes responsible for this distribution.

Acknowledgements. This research was funded by FAPESP (Sao Paulo Research Foundation no. 2008/09086-7, 2008/58089-9, and 2011/12770-0), INSU-Ec2co (National Institute of Sciences of the Universe) and UFMS (Federal University of South Mato-Grosso). L. Barbiero was supported by FAPESP (no. 2009/53524-1) and CAPES (Coordination of Improvement of Higher Education Personnel) grants.

Edited by: A. D. Reeves 


\section{References}

Alvarenga, S. M., Brasil, A. E., Pinheiro, R., and Kux, H. J. H.: Estudo geomorfológico aplicado à Bacia do Alto Paraguai e Pantanais Mato-grossenses, RADAMBRASIL projet, Technical Bulletin, Geomorphological Serie, Salvador-Brazil, 89-183, 1984.

ANA/GEF/PNUMA/OEA: Programa de ações estratégicas para o gerenciamento integrado do Pantanal e da bacia do Alto Paraguai, Final report, Brasilia, Brazil, 2004.

Assine, M. L.: River avulsions on the Taquari megafan, Pantanal wetland, Brazil, Geomorphology, 70, 357-371, doi:10.1016/j.geomorph.2005.02.013, 2005.

Baldwin, D. S. and Mitchell, A.: Impact of sulfate pollution on anaerobic biogeochemical cycles in wetland sediment, Water Res., 46, 965-974, doi:10.1016/j.watres.2011.11.065, 2012.

Barbiero, L., Valles, V., Régeard, A., and Cheverry, C.: Residual Alkalinity as a tracer to estimate the changes induced by a forage cultivation in a non saline sodic soil, Agr. Water Manage., 50, 229-241, doi:10.1016/S0378-3774(00)00124-4, 2001.

Barbiero, L., Queiroz Neto, J. P., Ciornei, G., Sakamoto, A., Capellari, B., Fernandes, E., and Valles, V.: Geochemistry of water and groundwater in the Nhecolândia, Pantanal of Mato Grosso, Brazil. Variability and associated processes, Wetlands, 22, 528-540, doi:10.1672/02775212(2002)022[0528:GOWAGW]2.0.CO;2, 2002.

Barbiero, L., Furquim, S. C., Valles, V., Furian, S., Sakamoto, A., Rezende Filho, A. T., Graham, R. C., and Fort, M.: Natural arsenic in Groundwater and alkaline lakes at the upper Paraguay basin, Pantanal, Brazil, in: Arsenic in Soil and Groundwater Environment: Biogeochemical interactions, Trace metals and other contaminants in the environment, edited by: Battacharya, P., Mukherjee, A. B., Bundschuh, J., Zevenhoven, R., Loeppert, R. H., and Nriagu, J. O., Vol. 9, Chapter 4, Elsevier Book Series, Amsterdam, The Netherlands, 101-126, doi:10.1016/S1875-1121(06)09004-3, 2007.

Barbiero, L., Rezende Filho, A. T., Furquim, S. A. C., Furian, S., Sakamoto, A. Y., Valles, V., Graham, R. C., Fort, M., Ferreira, R. P. D., and Queiroz Neto, J. P.: Soil morphological control of hydrogeochemistry in a saline and freshwater lake landscape in the Pantanal of Nhecolândia, Brazil, Geoderma, 148, 91-106, doi:10.1016/j.geoderma.2008.09.010, 2008.

Batzer, D. P. and Sharitz, R. R.: Ecology of freshwater and estuarine wetlands, University of California Press, Berkeley, CA, USA, 568 pp., 2006.

Brinson, M., Lugo, A., and Brown, S.: Primary productivity, decomposition and consumer activity in freshwater wetlands, Ann. Rev. Ecol. Evol. System., 12, 123-161, 1981.

Christophersen, N. and Hooper, R. P.: Multivariate analysis of streamwater chemical data: The use of principal components analysis for the end-member mixing problem, Water Resour. Res., 28, 99-107, doi:10.1029/91WR02518, 1992.

Furquim, S. A. C., Graham, R. C., Barbiero, L., Queiroz Neto, J. P., and Valles, V.: Mineralogy and genesis of smectites in an alkaline-saline environment of Pantanal wetland, Brazil, Clays Clay Min., 56, 579-595, doi:10.1346/CCMN.2008.0560511, 2008.

Furquim, S. A. C., Graham, R. C., Barbiero, L., Queiroz Neto, J. P., and Vidal-Torrado, P.: Soil mineral genesis and distribution in a saline lake landscape of the Pantanal wetland, Brazil, Geoderma, 154, 518-528, doi:10.1016/j.geoderma.2009.03.014, 2010a.
Furquim, S. A. C., Barbiero, L., Graham, R. C., Queiroz Neto, J. P., Ferreira, R. P. D., and Furian, S.: Neoformation of micas in soils surrounding an alkaline-saline lake of the Pantanal wetland, Brazil, Geoderma, 158, 331-342, doi:10.1016/j.geoderma.2010.05.015, 2010b.

Fustec, E. and Lefeuvre, J. C.: Fonctions et valeurs des zones humides, Dunod, Paris, France, 2000.

Girard, P., Fantin-Cruz, I., Loverde de Oliveira, S. M., and Hamilton, S. K.: Small-scale spatial variation of inundation dynamics in a floodplain of the Pantanal (Brazil), Hydrobiologia, 638, 223233, doi:10.1007/s10750-009-0046-9, 2010.

Gran, G.: Determination of the equivalence point in potentiometric titrations, Acta Chem. Scand., 4, 559-577, 1952.

Hamilton, S. K., Sippel, S. J., Calheiros, D. F., and Melack, J. M.: An anoxic event and other biogeochemical effects of the Pantanal wetland on the Paraguay River, Limnol. Oceanogr., 42, 257-272, 1997.

Hamilton, S. K., Corrêa de Souza, O., and Coutinho, M. E.: Dynamic of floodplain inundation in the alluvial fan of the Taquari River (Pantanal, Brazil), Verhandlungen der Internationale Vereinigung für theoretische und angewandte Limnologie, 26, 916922, 1998.

Hardie, L. A. and Eugster, H. P.: The evolution of closed-basin brines, Miner. Soc. Am. Spec. Pap., 3, 273-290, 1970.

Humphries, M. S., Kindness, A., Ellery, W. N., Hughes, J. C., Bond, J. K., and Barnes, K. B.: Vegetation influences on groundwater salinity and chemical heterogeneity in a freshwater, recharge floodplain wetland, South Africa, J. Hydrol., 411, 130-139, doi:10.1016/j.jhydrol.2011.09.041, 2011.

IBGE: Base cartográfica integrada digital do Brasil ao milionésimo: versão 1.0 para ArcGis Desktop-ArcView, IBGE CD-Rom, Rio de Janeiro, Brazil, 2003.

Jolly, I. D., McEwan, K. L., and Holland, K. L.: A review of groundwater - surface water interactions in arid/semi-arid wetlands and the consequences of salinity for wetland ecology, Ecohydrology, 1, 43-58, doi:10.1002/eco.6, 2008.

Junk, W. J. and da Cunha, C. N.: Pantanal: a large South American wetland at a crossroads, Ecol. Eng., 24, 391-401, doi:10.1016/j.ecoleng.2004.11.012, 2005.

Lamers, L. P. M., Tomassen, H. B. M., Roelofs, J. G. M.: Sulfateinduced eutrophication and phytotoxicity in freshwater wetlands, Environ. Sci. Technol., 32, 199-205, doi:10.1021/es970362f, 1998.

Lamers, L. P., Ten Dolle, M. G. E., Van Denberg, S. T. G., Van Delft, S. P. J., and Roelofs, J. G. M.: Differential responses of freshwater wetland soils to sulphate pollution, Biogeochemistry, 55, 87-102, doi:10.1023/A:1010629319168, 2001.

Liu, F., Williams, M., and Caine, N.: Source waters and flowpaths in a seasonally snow-covered catchment, Colorado Front Range, USA, Water Resour. Res., 40, W09401, doi:10.1029/2004WR003076, 2004.

Mitsch, W. J. and Gosselink, J. G.: Wetlands, 4th Edn., John Wiley and Sons, New York, 2007.

Por, F. D.: The Pantanal of Mato Grosso (Brazil): World's Largest Wetlands, Monographiae Biologicae, Springer, 1995.

Reddy, K. R. and DeLaune, R. D.: Biogeochemistry of wetlands: Science and applications, CRC Press Inc., Boca Raton, USA, 2008. 
Tooth, S., McCarthy, T., Rodnight, H., Keen-Zebert, A., Rowberry, M., and Brandt, D.: Late Holocene development of a major discontinuity in floodplain wetlands of the Blood River, eastern South Africa, Geomorphology, doi:10.1016/j.geomorph.2011.12.045, in press, 2012.

Turner K.: Economics and wetland management, Ambio, 20, 5963, 1991.

Valles, V., Pachepsky, Y. A., and Ponizovsky, A. A.: Invariant criteria for irrigation water quality assesment in arid and semi arid regions, in: Genesis and control of fertility of salt affected soils, ISSS Subcommission on salt affected soils Science, USSR, V. V. DOKUCHAEV Soil Institute, Moscow, 330-333, 1991.
Valles, V., Lefevre, A. M., and Ponizovsky, A. A.: Alkalization of nutrient solutions by sorghum, Comm. Soil Sci. Plant Anal., 24, 379-388, doi:10.1080/00103629309368808, 1993.

Whiting, G. and Chanton, J.: Greenhouse carbon balance of wetlands: methane emission versus carbon sequestration, Tellus B, 53, 521-528, 2001. 